\title{
古代エジプトの織物断片の劣化状態について
}

\author{
昭和女子大学 家政学部 小原奈津子 - 菊地美知子 - 中山 栄子 - 豊田 春和
}

\section{NATURAL AGEING OF THE ANCIENT EGYPTIAN LINENS}

Natsuko Kohara, Michiko Kikuchi, Eiko Nakayama, and Harukazu Toyoda

Department of Home Economics, Showa Women's University

Taishido 1-7.57, Setagaya-ku, Tokyo, 154 Japan

\begin{abstract}
Over 150 mummies had been found in one of the noble tombs (B. C. $15-16$ C.) on the west bank of the Nile in Luxor, Egypt.UAR by Egyptian culture center of Waseda University. The tombs were the rock-cut graves built in the slope of the low terrace. Six linen specimens, which had been used for mummy-cloth or a bandage in this tomb, were analysed and compared to modern linen with no chemical treatment. $56-126 \mathrm{mmol} / \mathrm{glucose}$ unit of aldehyde groups and $31-102 \mathrm{mmol} / \mathrm{glucose}$ unit of ketone groups were formed in the ancient linen by oxidation over the long period of time, while carboxyl groups were hardly detected. The linens exhibited low D. P., although neither the cellulose crystallinities nor the crystallite sizes in the lateral dimension, estimated with the $(020)$ reflection, were significantly different from each value of the modern linen. These facts suggest that the slow oxidation proceeded in such dry and dark environment as the tomb, and that the reaction especially in the crystalline regions were accompanied with the cleavage of the molecular chains rather than that of the inter-molecular hydrogen bonds by hydroxyl groups.
\end{abstract}

(Received August 5, 1991)

\section{1. 粕 詥}

早稻田大学古代エジプト調查委員会は, 昭和 57 年以 来, エジプト・アラブ共和国ケナ州ルクソール市西岸ク ルナ村で「貴族の墓」の発掘調査を行ってきた。この遺 跡は, クルナ村のシェイク・アフド・アル・クルナ地区 (Shikh' Abd al-Qurna)の標高約85 m の低位段丘の斜面 にうがたれた岩斑墓からなる。このうちの317号墓は, 第18王朝トトメス III 世の時期(B.C. 1502-1448頃)の のと考えられている「アメン神の款会の書記」の称号を 持つジェフティネフェルの墓とされている。墓の内部に は光は入らず暗いが，外部の空気とは通じしている。同 調查委員会によって，この墓から150体以上のミイラゃ 人骨，およびこれらに伴う包带，布片などが発掘された （1〕が，別報 [2]で報告したようにこれらの包带や 布片は，その織維形態と地理および歴史的背景から麻布 と考えられた。それらは約3000年も前のものと推定され ているにもかかわらず，また，強度はかなり低下してい
るものの，予想外に当時の形態を維持している。

セルロース織維の光による分化に関する研究は19世紀 後半に始められ，出化機構の解明を目的として，敞よ って起こる粘度低下と重量减少との関倷やセルロースの 光酸化反応の生成物の分析など，種々の角度加研㠰さ れている[3]。この遺跡のように乾燥地带の光の当たら ない環境下で，林峨維の劣化がどのように進むのかを解 明することは，七ルロースの保存科学の点からも興昧深 い。本研究では，これらの古代エジブトの麻布における セルロースの劣化機構の解明を最釉目的として，この 317 号墓から発掘された布および包带断片の中から6片 の麻布について，アルデヒド基，ケトン基およびかルボ キシル基の定量によってセルロース分子の酸化度を，誠 料のニト口化誘導体の粘度測定によって重合度をまた $\mathrm{X}$ 線回折により結晶化度と微結晶の幅 $\left(\mathrm{D}_{020}\right)$ を，現代の 麻布と比較して評価し，その少化状態について㛟討し た。 


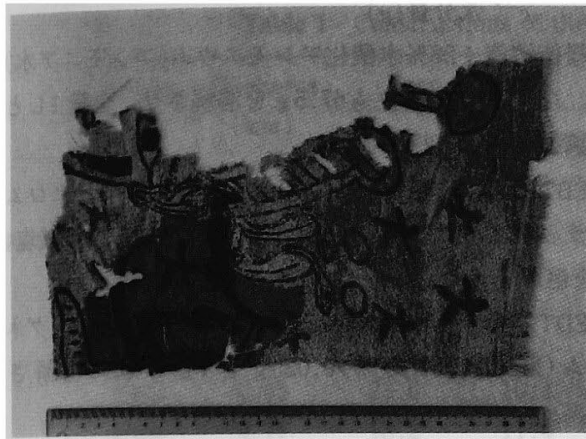

a)

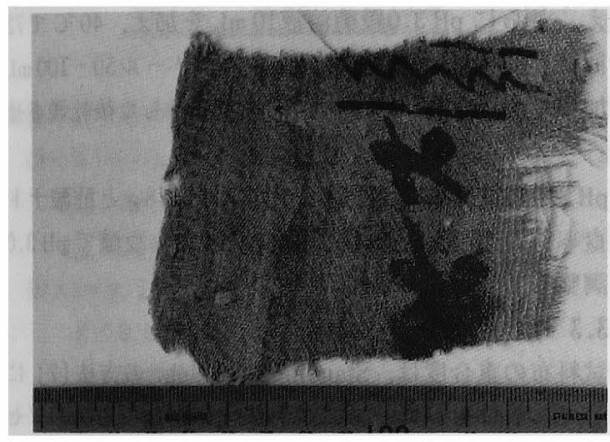

b)

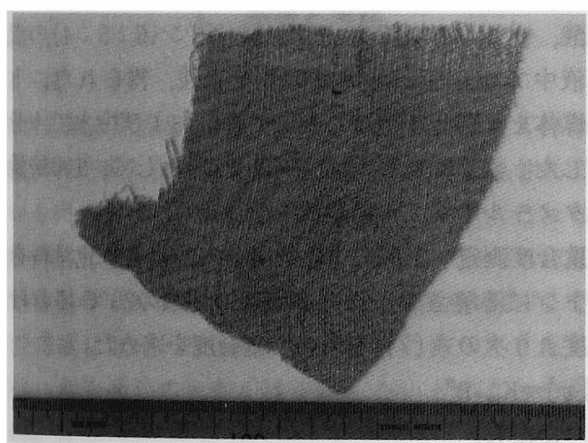

c)

Fig. 1. Photographs of the ancient Egyptian linens.

\section{2. 実跧}

\section{1 式 料}

試料はエジプ・・アラブ共和国ケナ州ルクソール市西 岸クルナ村のシェイク・アフド・アル・クルナ地区 (Sheikh' Abd al-Qurna)の標高85 m の低位段丘の斜面に うがたれた岩翁墓から発掘されたものである。その岩窟 墓は128，129，317，318，W2(未登録)号墓が連結して おり, 前述のように, 317号墓からは150体以上のミイラ

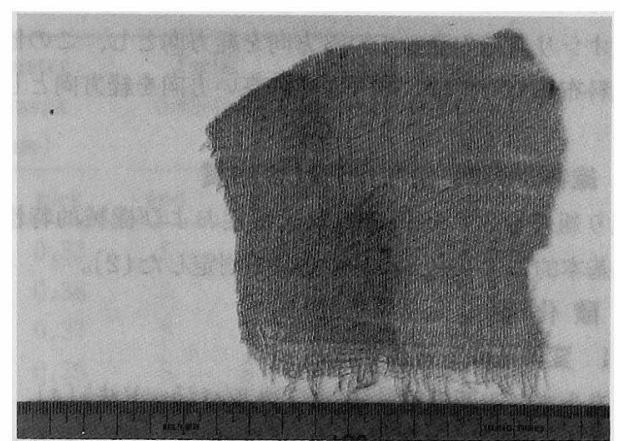

d)

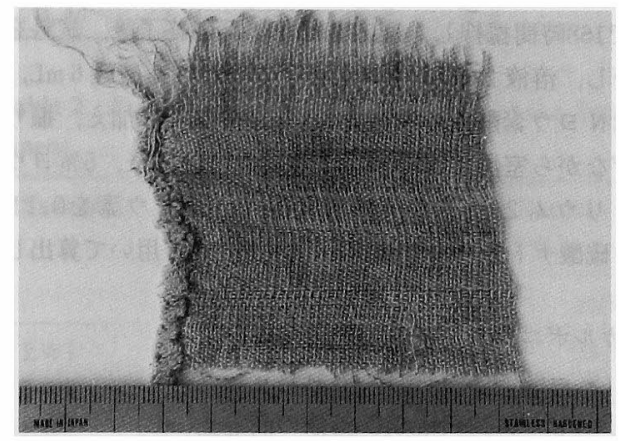

e)

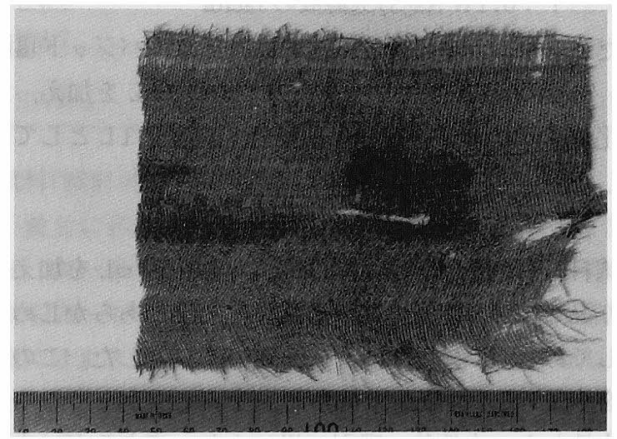

f)

a) EW1; b) EW2; c) EW3; d) EW5; e) EW6; f) EW7.

や人骨，それに伴う包帯の断片が発見されているが，本 研究では, これらの中から EW1, EW2, EW3, EW5, EW6，EW7 を試料として用いた。EW1 および2には彩 色が施されており，中でも EW1にはオシリス神やアヌ ビス神，ヘビの姿などが描かれている(図 1-a および b)。EW3〜 7 には図柄が描かれておらず，現在の色は 黄土一茶色であるが, おそらく当時も彩色はなされてい なかったものと見られる(図 1-c 〜 f)。

EW2 以外の試料布には耳組織がなく, 織物の経およ 
び緯方向が明確でない。そこで, 便宜上, EW1につい てはオシリス神の立っている方向を程方向とし，この他 の試料布については、織り密度の高い方向を経方向とし た。

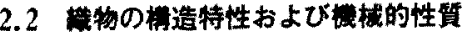

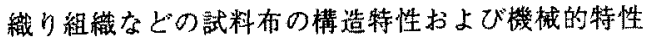
は、基本的にはJIS L-1096に準してて测定した(2)。

\section{3 酸化度}

\subsection{1 变䓄基の定典法}

1) カルボニル基の定量法(七ミカルバジッド法)【4]

セミカルバジッド溶液 $50 \mathrm{~mL}$ に試料0.1-0.2 g ある は业塩素酸塩酸化試料 $0.1-0.3 \mathrm{~g}$ を精科して加え, 25 ${ }^{\circ} \mathrm{C}$ で168時間㩧捧し，反応させた。反応終了後，試料を 除去し，溶液 $2 \mathrm{~mL}$ を分取した。これ $0.02 \mathrm{~N}$ ヨウ素酸方りウム $5 \mathrm{~mL}$ をこの頌序で如之，振り 漉ぜながら室温で20分間反応させた。反応後，5\%ヨウ 化为りウム $2 \mathrm{~mL}$ 加え，避㒕してきたヨウ素を0.1 N チオ硫酸ナトリウムで滴定し，以下の式を用いて算出し t。

カルボニル基墨 (mmol/glucose unit)

$=62.5 \times(\mathrm{a}-\mathrm{b}) \times \mathrm{f} /$ 試料 $\mathrm{g}$ 数

a $: 0.1 \mathrm{~N} \mathrm{Na}_{2} \mathrm{~S}_{2} \mathrm{O}_{3}$ 溶液の滴定量 $(\mathbf{m L})$

$\mathrm{b}$ : 同上空試験值 $(\mathrm{mL})$

f : $0.1 \mathrm{~N} \mathrm{Na}_{2} \mathrm{~S}_{2} \mathrm{O}_{3}$ 溶液 $の$ factor

ただし，セミカルバジッド溶液はセミカルバジッド壏酸 塩 $1.74 \mathrm{~g}$ に0. $2 \mathrm{~N}$ 篗フタル酸カリウ $250 \mathrm{~mL}$ を加え，水 酸化ナトリウムで pH 4.0に調整し，全量を1Lとして調 製した。

2)力ルボキシル基の定量法 [5]

試料 $0.2 \mathrm{~g}$ を精科し，これに0.1 $\mathrm{N}$ 塩酸 $15 \mathrm{~mL}$ を加え， 振り混ぜながら公温で30分間洗浄した後，あらかじめ科 量してあるグラスフィルターを用いてロ過した。この試 料を少量の0.1 N 塩酸で洗浄し，続いて酸がなくなるま で水洗した。水洗後，吸引口過により，でさるだけ水分 を取り除きフフィルターごと科量して試料中に残存する 水分量を算出した。次に，分液口ートに $0.34 \mathrm{mN}$ 䣫酸力 ルシウム溶液 $60 \mathrm{~mL}$ をと，試料の入ったフィルターに 滴下し，この操作を，溶液を得環させながら30分間繰り 返した。この後，口液 $10 \mathrm{~mL}$ 分取し，縓㣫溶液 $0.3 \mathrm{~mL}$ を加え，指示綝として EBT 試薬を加え，溶液の赤色が 完全に消失するまでEDTA 溶液で滴定し，以下の式を 用いて算出した。

カルボキシル基量(mmol/glucose unit)

$=0.162 \times 160 \times(\mathrm{a}-\mathrm{b})-\mathrm{b} \times \mathrm{c}\} /$ 試料 $\mathrm{g}$ 数

$\mathrm{a}:$ : カルシウム溶液濃度 $(\mathrm{mN})$

$\mathrm{b}$ : 口夜濃度 $(\mathrm{mN})$ $\mathrm{c}:$ 水分量 $(\mathrm{g})$

㣪湩溶：28\%水酸化アンモニウム(アンモニア水)中 に，瑥化アンモニウム $67.5 \mathrm{~g}$ 溶解させ，全量 $1 \mathrm{~L} と し$ て觡製しだ。

EBT 指示薬：メタノール $100 \mathrm{~mL}$ 中にエリオクロム。 ブラック $\mathrm{T}(\mathrm{EBT}) 0.5 \mathrm{~g}$ とヒドロキシルアミン塩酸塩 4.5 $\mathrm{g}$ を溶解させた。

EDTA 溶液：EDTA2 ナトリウム塩 $1 \mathrm{~g}$ ，塩化マグネシ ウ $厶\left(\mathrm{MgCl}_{2} \cdot 6 \mathrm{H}_{2} \mathrm{O}\right)$ 約 $0.025 \mathrm{~g}$ 学 $1 \mathrm{~L}$ の水に溶解させ to

\section{3 .2 垔塩秦酸酸化法 $[6]$}

試料布 $0.7 \mathrm{~g}$ に水 $10 \mathrm{~mL}$, 垔塩素酸十トリウ $40.7 \mathrm{~g}$ 加え，さらに $\mathrm{pH} 3.0$ 䌅衝溶液 $10 \mathrm{~mL}$ を加え，40 $\mathrm{C}$ で? 時間酸化させた。店終了後，メ夕ノール50-100 mL 注加してから口過し、メタノールで流浄した後乾煤させ た。

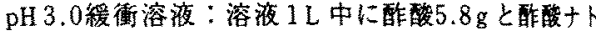
リウム $8.2 \mathrm{~g}$ を溶かし，さらに少量のシュウ酸で $\mathrm{pH} 3.0$ に調整して得た。

\subsection{3 重合度}

試料布の重合度は, Staudinger とMohr の方法 [7] 準じて二トロセルロースに誘暹体化しこのもののフセ トン溶液の粘度から求奶た。

ニトロ化：乾燥させな試料 $0.1-0.2 \mathrm{~g} / 100 \mathrm{~g}$ の発焐 硝酸，オルソリン酸拐よび五酸化りン(6:5:4)の搌合 溶液中で $0{ }^{\circ} \mathrm{C}$ で 12 時間反応させた媵，得られたニト口 誘導体を口別し，冷却した50\%酢酸拉よび命水で十分洗 净した。洗浄㣪，試料の安定化処理として，100倍量の メタノール中で 2 時間造流した。

重合度測定：上記の方法で得られたニト口化試料を?

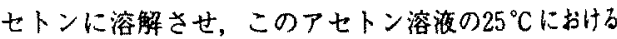
粘度より次の式 (7) を用いて重合度求めた。

$$
\begin{gathered}
{[\eta]=K_{\mathrm{m}} \cdot \mathrm{p}^{\alpha}} \\
\text { たたし, } \\
\mathrm{K}_{\mathrm{m}}=11 \times 10^{-4} \\
\alpha=1
\end{gathered}
$$

\section{4 結晶化度および結㬎領域の幅}

$\mathrm{X}$ 線回折装置ガイガーフレックス RAD-M B(理学電倠 彆)でニオメーターCN2155*6 考用いてX線回折法 (反射法)で測定した。X線は、ニッケルフィルターで車 色化しなCuKa 線を用いだ。試料は総じて引張りなどけ 外力により容易に破断するため，試料をそのまま武糊架 に固定し，测定に供した。各陚料の020面等の回折强度 および干涉幅から，Segal らの方法 (8)により結晶度指 数を結晶化度として(式 1)，また，Scherrer 式(9)(式

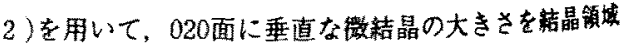


Table 1 Constructions of the Ancient Linens and the Weaving Yarns

\begin{tabular}{|c|c|c|c|c|c|c|c|c|c|}
\hline \multirow[t]{3}{*}{ Sample } & \multirow{3}{*}{$\begin{array}{c}\text { Thickness } \\
(\mathrm{mm})\end{array}$} & \multicolumn{2}{|c|}{ Yarn density } & \multirow{2}{*}{\multicolumn{2}{|c|}{$\begin{array}{c}\text { Diameter } \\
\text { of yarns } \\
(\mathrm{mm})\end{array}$}} & \multirow{2}{*}{\multicolumn{2}{|c|}{$\begin{array}{c}\text { Twist } \\
\text { direction }\end{array}$}} & \multirow{2}{*}{\multicolumn{2}{|c|}{$\begin{array}{l}\text { Twist number } \\
\text { (turns/inch) }\end{array}$}} \\
\hline & & \multirow[t]{2}{*}{ ends/cm } & \multirow[t]{2}{*}{ picks/cm } & & & & & & \\
\hline & & & & end & pick & end & pick & end & pick \\
\hline EW1 & 0.73 & 11.4 & 16.8 & 0.44 & 0.33 & S & $S$ & 19.4 & 18.8 \\
\hline EW2 & 0.75 & 22.6 & 12.6 & 0.38 & 0.38 & S & $S$ & 14.5 & 15.2 \\
\hline EW3 & 0.61 & 22.6 & 11.0 & 0.28 & 0.37 & $\mathrm{~S}$ & $S$ & 18.8 & 27.1 \\
\hline EW5 & 0.65 & 23.6 & 10.4 & 0.27 & 0.39 & $S$ & S & 29.6 & 15.8 \\
\hline EW6 & 0.77 & 18.2 & 11.4 & 0.41 & 0.39 & $\mathrm{~S}$ & $S$ & 15.2 & 13.7 \\
\hline EW7 & 0.64 & 20.2 & 10.6 & 0.33 & 0.36 & S & S & 15.5 & 21.4 \\
\hline SW1-a & 0.63 & 15.0 & 13.7 & 0.45 & 0.44 & $Z$ & $Z$ & 8.3 & 8.4 \\
\hline
\end{tabular}

の幅として求めた。

$$
\begin{aligned}
& \operatorname{Crl}(\%)=\left\{\left(\mathrm{l}_{020}-\mathrm{I}_{\mathrm{am}}\right) / \mathrm{I}_{020}\right\} \times 100 \\
& \mathrm{I}_{020}: 2 \theta=22.8^{\circ} \text { における }(020) \text { 面の干涉强度 } \\
& \mathrm{I}_{\mathrm{am}}: 2 \theta=18.0^{\circ} \text { における非晶領域による干涉強度 } \\
& D(A)=k \cdot \lambda /(B \cdot \cos \theta) \\
& \mathrm{K}: 0.9 \text { (定数) } \\
& \theta: \text { 回折角 (degree) } \\
& \text { B : 半洒幅( radian) } \\
& \lambda \text { : 入射 } \mathrm{X} \text { 線の波長 }\left(1.54 \times 10^{-1} \mathrm{~nm}\right)
\end{aligned}
$$

\section{3. 結果と考察}

\section{1 试 料}

EW1 およU゙ 2 は顔料でオシリス神やアヌビス神など が描かれた彩色布片であるが，他の試料は彩色されてい ないものでありこれらの写真を図 1 に示す。これらの 試料が発掘された墓内は光が全く入らす，1990年12月29

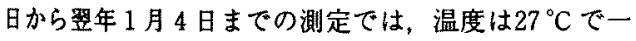
定で湿度は22.0-26.0\%R.H.の範囲にありこれらの 値は一年を通じて大きくは変動しないとのことである (10)。

EW1 および2の彩色されていない部分と EW3， $5 ， 6$ および7の現在の色は，黄士一茶色である。EW1に関 しては，ピンセット等で織物表面の顔料を削り取ったの みで分析に用いた。EW2の彩色されていない部分およ びその他の試料については，メタノールおよび水中に浸 瀆し，室温で振とうした。この洗浄によって，樹脂など に起因すると思われる茶色の着色物質の一部が抽出さ れ, 陚料重量の14-16\%が隇少した。発掘試料はすべて 平織の麻(すなわちリネン)であった。試料の織り組織, 较り系の棈造と引張り强伸度については別報 (2) で報 告するが，简単に表 1 に示す。また、比較のため，これ らの発嗰試料布に近い番手の糸で織られた現代の麻布も
Table 2 Physical Properties of the Yarns of the Ancient Linens

\begin{tabular}{lrrrrr}
\hline Sample & \multicolumn{2}{c}{$\begin{array}{c}\text { Tensile strength } \\
\left(\mathrm{g} / \mathrm{mm}^{2}\right)\end{array}$} & & \multicolumn{2}{c}{$\begin{array}{c}\text { Elongation } \\
(\%)\end{array}$} \\
\cline { 2 - 3 } \cline { 6 - 7 } & end & pick & & end & pick \\
\hline EW1 & 45 & 89 & & 10.5 & 23.1 \\
EW2 & 331 & 806 & & 5.3 & 5.2 \\
EW3 & 603 & 490 & & 14.5 & 11.4 \\
EW5 & 516 & 358 & & 12.6 & 8.9 \\
EW6 & 273 & 545 & & 18.1 & 10.5 \\
EW7 & 399 & 399 & & 14.3 & 6.6 \\
SW1-a & 15971 & 17895 & & 10.5 & 6.1 \\
\hline
\end{tabular}

試料(試料名：SW1-a)として用いた。

表 2 に示すように，発掘試科の織り系の引張り強度 は，同一試料でもバラッキがあるが，総じて，SW1-a の1/22-1/328にも低下している。一方, 引張り伸度の 值には大きな差は認められず，現代の麻布よりむしろほ とんどの発掘試料の方がわずかに大きい。

\section{2 化度}

光によるセルロースの分解は酸素の存在で促進される ことが一般に知られている。これらの試料は，光の当た らない岩窟墓で発掘されたが,この場所は，外界の空気 が流入しうる場所であるため，発掘試料のセルロース分 子は酸化を受けている可能性がある。そこで，セルロー ス分子中のケトン基，アルデヒド基捛よびカルボキシル 基の定量分析を行った。

織維中のケトン基量およびアルデヒド基量は七ミカル バジッド法 [4]で測定した。セミカルバジッド塩酸塩 は, $\mathrm{pH} 4$ の溶液中でカルボニル基に定量的に付加す る。過剩の七ミカルバジッドと試料转維を反応させ，下 式に示すように，溶液中に残留しているセミカルバジッ 
ドを酸化還元滴定することによって轼維中のカルボニル 基量を測定する方法である。

$$
5 \mathrm{NH}_{2} \mathrm{CONHNH}_{2} \cdot \mathrm{HCl}+4 \mathrm{KIO}_{3} \rightarrow 2 \mathrm{I}_{2}
$$

$\mathrm{KIO}_{3}+5 \mathrm{KI} \rightarrow 3 \mathrm{I}_{2}$

$\mathrm{I}_{2}+2 \mathrm{Na}_{2} \mathrm{~S}_{2} \mathrm{O}_{3} \rightarrow 2 \mathrm{NaI}+\mathrm{Na}_{2} \mathrm{~S}_{4} \mathrm{O}_{6}$

まず，同法でカルボニル基量を，ケトン基とアルデヒド 基量の和として求めた。次に，覀塭素酸ナトリウムを用 いて同試料中のアルデヒド基のみを選択的にカルボキシ ル基に酸化させ,この酸化試料について再びセミカルバ ジッド法でケトン基量を測定した。アルデヒド基量は， 先に求めたカルボニル基量とケトン基量との差として求 めた。

カルボキシル基量は，ダイナミックイオン交換法 [5] により測定した。過剩の酢酸カルシウム溶液と試料織維 を接触させて，践維中のカルボキシル基と反応させた 後，溶液に残存している未反応の $\mathrm{Ca}^{2+}$ イオンを EDTA 滴定で定量することによってカルボキシル基量を求め た。試料と分析試薬との反応時間を，七ミカルバジッド 法では7 日間以上,ダイナミックイオン交換法では72時 間以上に延長しても得られた変質基量が増加することは なかった。

これらの分析で求めた試料中のアルデヒド基，ヶトン 基およびカルボキシル基量を表 3 に示す。現代の麻布に

Table 3 Oxidation Stages of Ancient Linens

\begin{tabular}{lrrr}
\hline Sample & Aldehyde group & $\begin{array}{c}\text { Ketone group } \\
\text { (mmol/glucose unit) }\end{array}$ & Carboxyl group \\
\hline EW1 & 56 & 102 & 1 \\
EW2 & 75 & 50 & 5 \\
EW3 & 70 & 31 & 6 \\
EW5 & 126 & 38 & 6 \\
EW6 & 67 & 57 & 5 \\
EW7 & 117 & 51 & 8 \\
SW1-a & 15 & 6 & 5 \\
\hline
\end{tabular}

比ベ，カルボキシル基量はほとんど変化していないが， アルデヒド基は約 4-8倍, ケトン基は 5-17倍に增加 している。表 3 から、たとえばEW1の場合，100個の ダルコース残基あたり，平均 5-6個のアルデヒド基お よび10個のケトン基が存在することになる。このよう に，発掘試料のセルロースは明らかに酸化を受けている が，少なくとも現時点では，生成したアルデヒド基ある いはケトン基がさらに酸化されカルボキシル基を生成す るには至っていないことがわかる。

\section{2 亩合度}

これらの試料の劣化の原因の一つとして，少なくとも
酸化が起こっていることが先の結果からわかったが、 こ のような部分的に変性したセルロースの正確な分子量を 測定することは，容易ではない。粘度による湘定法にっ いても，発掘試料のように部分的に酸化あるいは変性し たセルロース分子の重合度測定に必ずしも最適な法と はいえないが，現時点でセルロースの分子量の最し一杸 的な測定法である粘度法を用いて重合度の測定を試み た。測定に先立ち, Staudinger とMohrの方法 (7)に染 じて試料をニトロ化しアセトンに可溶化させてからアせ トン溶液として粘度を測定した。

Table 4 Degrees of Polymerization of Ancient Linens Nitrated

\begin{tabular}{lc}
\hline Sample & D. P. \\
\hline EW1 & 420 \\
EW2 & 250 \\
EW3 & 236 \\
EW5 & 253 \\
EW6 & 309 \\
EW7 & 281 \\
SW1-a & 3090 \\
\hline
\end{tabular}

表 4 で示すように，現代の麻布の重合度が3090である のに対して, 発掘試料の重合度はその $1 / 7-1 / 13 に$ 滍少 していることがかかる。Kleinert〔11]は紀元前2000年 および同1500年の古代エジプトのリネンの重合度が，そ れぞれ269および225であることを報告しているが，これ らの值は本研究で得られた値とよく一致している。

\section{3 結晶化度および結晶领域の䀅}

$\mathrm{X}$ 線回折法で Segal の方法 (8)に準してて武料㧴維の榙 晶度指数を結晶化度として, また, 結晶領城の幅とし て. Scherrer 式 [9] を用いて020面の干涉幅よりこれに 垂直な方向の微結晶の大きさを測定した。これらの模果 を表 5 に示す。発掘試料の結晶度指数は現代の麻布とそ

Table 5 Crystallinity Indices ( $\mathrm{CrI}$ ) and Crystallite Sizes in the Lateral Dimension $\left(D_{020}\right)$ of the Ancient Linens

\begin{tabular}{lcc}
\hline Sample & CrI $(\%)$ & $D_{020}(\mathrm{~nm})$ \\
\hline EW1 & 73 & 4.3 \\
EW2 & 62 & 5.8 \\
EW3 & 73 & 5.1 \\
EW5 & 71 & 5.5 \\
EW6 & 63 & 4.7 \\
EW7 & 68 & 5.3 \\
SW1-a & 62 & 4.7 \\
\hline
\end{tabular}


れほど大きな差は認められず，むしろやや增加している 傎が見られた。また，すべての試料の $\mathrm{D}_{020}$ の值は 4.3 - $5.8 \mathrm{~nm}$ の範囲にあり，各試料間に影著な差異は認めら れない。れらのことは，結晶構造は，020面に垂直な 方向にかいては大きな変化がなかったことを示してい る。一方, SW1-a と EW2のX 線回折写真を比較する と，SW1-a で観察された002面の千涉が EW2 では見ら れず，結晶の軸方向に替則性がなくなっていることが先 の研究で示唆された [12]。これらのことから，結晶領 域におけるセルロース分子の変質は较維表面から内部へ 均一に進行するよりもむしろ，械維軸方向に不連続的に 起こっていることが考えられる。

\section{4. 結 铪}

以上の結果を総合すると、この遺跡のような低湿度で 光の当たらない環境下では，セルロース分子の分解反応 の一つとして革い酸化反応が進行しており，アルデヒド 基およびケトン基は生じているが，カルボキシル基の生 成には至っていなかった。また，七ルロース分子鎖の切 断も起こっており，重合度は，比較試料として用いた現 代の麻布の1/7-1/13に低下していた。これらの結果に 加えて，(020)面の回折強度を用いて求めた結晶度指数 は現代の麻布の値とほほ等しかったこと, 結晶領域の幅 $\left(\mathrm{D}_{020}\right)$ も比較試料の值と比へ，大きな差は認められなか ったこと，先の研究結果から示唆されたように，結晶の 軸方向の规則性が失われていることも考虑すると, 次の ことが結論される：乾燥した暗所での長期にわたる保存 により，麻布のセルロースでは，主としてグリコシド結 合の酸化がゆっくりと進行し，分子鎖の切断が起こって いると考えられる。一般に，このような酸化を含む分解 反応はまず非晶領域で起こり，さらに少化が進むにつ れ，結晶領域へと進行していくことが予測されるが，令
回得られた結果から，結晶領域におけるセルロース分子 鎖の分解は，䋞維表面から内部へ進行するよりもむし ろ, 瀻維軸の方向に不連続的に進行している可能性が高 wo

\section{部辞}

本研究を進めるにあたり，御指遒いただいた昭和女子 大学家政学部故大野泰雄教授，発掘試料を御提供いただ いた早稲田大学文学部榄井清彦教授，また，発掘場所の 気候に関し御教授いただいた昭和女子大学家政学部故江 本義理教授に媣謝の意を表します。

\section{文献}

1. 桜井清彦, 吉村作治, 吉成 葶, 近藤二郎, 考古学 ジャーナル, 253，35(1985)

2. 菊地美知子, 小原奈津子, 投稿準備中

3. B. Ranby, "Wood Processing and Utilization", (J. F. Kennedy, G. O. Phillips and P. A. Williams Ed.), Ellis Horwood Limited, Chichester, p. 353 (1989)

4. 山本純三郎, 宮田 徹, 工化, 62, 1433 (1959)

5. M. Sobue and M. Okubo, Tappi, 39, 415 (1956)

6. W. K. Wilson and A. A. Padgett, Tappi, 38, 292 (1955)

7. H. Staudinger and R. Mohr, Ber, 70, 2296 (1937)

8. L. Segal, J. J. Creely, A. E. Martin, Jr., and C. M. Conrad, Text. Res. J., 29, 786 (1959)

9. J. L. Hengstenberg and H. Mark, Z. Krist, 69, 271 (1928)

10. 江本義理, 日本文化財科学会, 日本文化財科学会第 8 回大会研究発表要旨集, p. 43 (1991)

11. T. N. Kleinert, Holzforschung, 26, 46 (1972)

12. 中山栄子, 菊地美知子, 小原奈津子, 昭和女子大学 䄫要「学苑」，614，26（1990） 